\title{
Criminalising Fabricated Images of Child Pornography: A Matter of
}

\author{
Harm or Morality?
}

Suzanne Ost ${ }^{*}$

INTRODUCTION

Certain provisions within the Coroners and Justice Act 2009 (C\&JA) have resulted in significant revisions to the criminal law and justice system and have thus understandably attracted media coverage and legal commentary. ${ }^{1}$ However, there is one offence that has received surprisingly scant attention. Following hot on the heels of the recent criminalisation of extreme pornography, ${ }^{2}$ the offence

\footnotetext{
* Law School, Lancaster University. I am grateful to Sara Fovargue and Peter Rowe for their valuable feedback on earlier versions of this paper. Thanks are also due to the Legal Studies reviewers and to Jenny Steele for their very helpful comments. Any errors remain my responsibility.

${ }^{1}$ For example, the provision that introduced a Sentencing Council for England and Wales which imposes guidelines for judges (s.118), and the provision which removed the requirement of the defendant's consent to the use of a live link for a preliminary hearing of her/his case (s.106). See 'Judges Group Attack Sentence Plan' BBC News, 25 March 2009, http://news.bbc.co.uk/1/hi/uk/7963321.stm; A Turner, 'Criminal Justice Legislation' (2010) 174(12) Criminal Law and Justice Weekly 162; 'Coroners and Justice Bill' (2009) 65 Magistrate 13; 'Thousands of Criminal Suspects to be Tried in Virtual Courts' The Times, 18 May 2009; Law Society, 'Law Society warns against removal of consent to hearings by 'virtual court', Press Release, 27 January 2009, http://www.lawsocietymedia.org.uk/site.php?s=1\&content=35\&press release $i d=1034 \& m t=34$. Unsurprisingly, unsuccessful amendments to the Coroners and Justice Bill (C\&JB) to change the law on assisted suicide also attracted media attention. See, for example, 'Hewitt Seeking Suicide Law Change', BBC News, 20 March 2009, http://news.bbc.co.uk/1/hi/uk_politics/7953570.stm; 'Hewitt Leads Call to Protect Suicide Helpers', The Independent, 20 March 2009; 'Assisted Suicide Ban Forcing Terminally III to Die Early, Lords told', The Guardian, 2 June 2009; 'Change in Assisted Dying Law Rejected', BBC News report, 7 July 2009, http://news.bbc.co.uk/1/hi/health/8139621.stm. All web pages last visited 3 January 2010.

${ }^{2}$ Criminal Justice and Immigration Act 2008 (CJIA), s.63. Extreme pornographic images are defined as 'pornographic images that depict acts which threaten a person's life, acts which result
} 
criminalises non-photographic pornographic images of children (NPPIC). That is, fantasy visual representations of child pornography in the form of, for example, computer generated images, cartoons or drawings. Such images are not prohibited by existing offences relating to indecent photographs of children, which only extend to images that are photographic, or appear to be photographic in nature, or are derived from a photograph. ${ }^{3}$ The Government's intention to make NPPIC unlawful became clear in 2007 , following the publication of a Home Office Consultation Paper. ${ }^{4}$ In this document, two primary harm based arguments were utilised to legitimate criminalisation: first, that NPPIC may be used to groom children and, secondly, that they could 'fuel abuse of real children by reinforcing potential abusers' inappropriate feelings towards children'. ${ }^{5}$

What is especially noteworthy is that the proposal to criminalise NPPIC was not made as a consequence of any research which demonstrated that such visual depictions are harmful. Indeed, in the Consultation Paper, it was stated that:

We are unaware of any specific research into whether there is a link between accessing these fantasy images of child sexual abuse and the commission of offences against children, but it is felt by police and

in or are likely to result in serious injury to a person's anus, breasts or genitals, bestiality or necrophilia'. See Explanatory Notes to the Criminal Justice and Immigration Act 2008 (2008), para 43; CJIA, s.63(7); C McGlynn and E Rackley, 'Criminalising Extreme Pornography: a lost opportunity' [2009] Criminal Law Review 245.

${ }^{3}$ See below nn 15, 16, 67 and 70 .

${ }^{4}$ Home Office, Consultation on the Possession of Non-photographic Visual Depictions of Child Sexual Abuse (London: Home Office, 2007).

${ }^{5}$ Ibid, p 5. 
children's welfare organisations that the possession and circulation of these images serves to legitimize and reinforce highly inappropriate views about children. ${ }^{6}$

It is apparent, then, that the stated justification for the offence was the possible harm that may be caused to children. As I will discuss, the Government has taken the same route as the US Congress, by adding to laws that protect morals to criminalise material that cannot be caught under existing legislation relating to indecent photographs of children. However, this move cannot be justified by relying on the classical liberal harm based rationale for prohibiting real images of child pornography. It cannot be argued that primary harm has been caused to the children who feature in the photographs, which is exacerbated by the knowledge that their abuse is recorded in images made available to others to view because, in the case of fantasy NPPIC, no real child has been abused. ${ }^{7}$ Yet the Government still considered the offence to be the next essential step in extending the legal protection offered to children from behaviour that is connected (directly or remotely) to sexual abuse. ${ }^{8}$

This should not come as a surprise. We live in a society in which children are categorised and distinguished as a special vulnerable group, as victims in

\footnotetext{
${ }^{6}$ Ibid, p 1.

${ }^{7}$ As I will discuss, the exception to this is where the NPPIC is a manipulated real photograph of child pornography or depicts real child sexual abuse.

${ }^{8}$ For example, at the beginning of the second reading of the C\&JB in the House of Commons, the Secretary of State, Jack Straw, stated that: 'In the past 10 years, we have developed much greater protection for children from sexual abuse, but we must keep the law up to date with technological changes. The Bill therefore provides for a new offence of possession of nonphotographic images of child sex abuse, building on the existing law in respect of indecent photographs.' Hansard, HC Deb, 26 January 2009: column 35.
} 
need of protection. Child sexual abuse and related acts are, understandably, seen as particularly grievous evils from which society must endeavour to protect children. ${ }^{9}$ In fact, the protectionist discourse surrounding children and sexual abuse has become so compelling that it is difficult to respond objectively when we perceive children to be at threat; we have reached a point where any behaviour that is connected to any form of child pornography is automatically considered to be harmful. ${ }^{10}$ However, whilst it would be extremely difficult to claim that an individual who creates real child pornography ${ }^{11}$ or disseminates such material has not caused harm to children, in the case of possessing NPPIC, the individual concerned may not have caused any direct harm to children by his $^{12}$ actions.

In this paper, I contend that a stronger case for criminalisation would have existed had the Government directed the new offence to NPPIC depicting real

\footnotetext{
9 See, for example, M Kleinhans, 'Criminal Justice Approaches to Paedophilic Sex Offenders', (2002) 11 Social and Legal Studies 233.

${ }^{10}$ See S Ost, Child Pornography and Sexual Grooming: Legal and Societal Responses (Cambridge University Press, 2009), pp 10-11.

${ }^{11}$ By the phrase 'real child pornography', I mean material which features the sexual abuse of real children.

${ }^{12}$ When referring to possessors of NPPIC, I use the masculine pronoun throughout this paper since the existing research indicates that the majority of individuals who use child pornography are male (see MC Seto and AW Eke, 'The Criminal Histories and Later Offending of Child Pornography Offenders' (2005) 17(2) Sexual Abuse: A Journal of Research and Treatment 201, p 203). However, this is certainly not to say that only men engage in such activities. Note the charges of sexual assault and making, distributing and possessing indecent images of children brought against nursery worker Vanessa George in 2009, who subsequently pleaded guilty to the offences and received an indeterminate sentence. One of the two co-defendants in the case was also female. For a history of the case, see 'Nursery School Worker on Charges of Child Porn Meets Parents' Anger Face to Face', The Guardian, 11 June 2009; 'The Hidden Truth', The Guardian, 12 June 2009; 'Nursery worker names sex victims' BBC News, 29 October 2009, http://news.bbc.co.uk/1/hi/england/devon/8331284.stm. Last visited 3 January 2010; 'Sentencing date for nursery worker paedophile', The Independent, 11 November 2009; 'Vanessa George jailed for child sex abuse', The Guardian, 15 December 2009. See also 'It's not just men who abuse', The Guardian, 10 November 2009. For clarity of exposition, I use the feminine pronoun when referring to the child.
} 
child sexual abuse, or featuring real children. I should note at the outset that I adopt a liberal, Millian approach in my analysis. ${ }^{13}$ Thus, I start from the premise that it is only when behaviour causes harm to others that there is a valid reason to limit liberty through criminal prohibition. Essentially, my position is that harm may be caused to children by NPPIC that are depictions of real child sexual abuse, or of the fantasy sexual abuse of a real, recognisable child. Hence, criminalisation of the creation, distribution and possession of these images is justified on the basis of the harm principle. ${ }^{14}$ And adopting a broader notion of harm, since creating and distributing NPPIC (including completely fabricated images) encourages the propagation of harmful attitudes towards children, criminalisation of such behaviour can also be justified according to a harm based rationale. However, it is extremely difficult to find a legitimate basis for criminalising the possession of fantasy, completely fabricated NPPIC through a reasoned application of the classical liberal harm principle. Morality based rationales for prohibiting NPPIC may be raised, but ultimately they fail to convince unless it is accepted that either legal moralism or moral paternalism are acceptable grounds for criminalisation, a position that liberalism rejects. I begin this paper by outlining the new offence before considering morality and harm based rationales for prohibiting the possession of NPPIC. This leads me to

\footnotetext{
13 JS Mill, On Liberty in JS Mill, Utilitarianism, On Liberty, Considerations on Representative Government (London: Orion, 1993), p 69.

${ }^{14}$ That is, Mill's avoidance of harm principle: 'The object of this Essay is to assert one very simple principle, as entitled to govern absolutely the dealings of society with the individual in the way of compulsion and control, whether the means used be physical force in the form of legal penalties, or the moral coercion of public opinion. That principle is, that the sole end for which mankind are warranted, individually or collectively, in interfering with the liberty of action of any of their number, is self-protection. That the only purpose for which power can be rightfully exercised over any member of a civilized community, against his will, is to prevent harm to others. His own good, either physical or moral, is not a sufficient warrant.' Ibid, p 78.
} 
suggest two ways in which the offence could have been framed to better target harm. Finally, I highlight specific elements of the offence which I conceive to be problematic. It is my contention that the offence is overbroad and vague and that its potential violation of privacy, freedom of expression and the principle of legal certainty raises concerns which cannot simply be alleviated by claiming it is necessary to protect the rights and freedoms of others.

\section{THE NEW OFFENCE}

The new offence can be found under sections 62-68 of the C\&JA. As with the existing offences relating to indecent photographs of children under the Protection of Children Act 1978 (PCA), ${ }^{15}$ and Criminal Justice Act 1998 (CJA), ${ }^{16}$ the provisions focus on the character of the image. Rather than being indecent, the image must be 'grossly offensive, disgusting or otherwise of an obscene character'. In addition, the image must be 'pornographic', that is, its nature means it must 'reasonably be assumed to have been produced solely or principally for the purpose of sexual arousal' ${ }^{17}$ These character requirements of NPPIC are identical to those of extreme pornographic images under the CJIA. ${ }^{18}$

\footnotetext{
${ }^{15}$ Under $\mathrm{s.1}$ of the PCA, it is an offence to take or permit to be taken an indecent photograph of a child, to distribute or show such a photograph, to have such a photograph in one's possession with a view to distribution, or to publish any advertisement that conveys that the advertiser distributes or shows such photographs or intends to do so.

${ }^{16}$ The CJA criminalises the possession of indecent photographs of children (s.160).

${ }^{17} \mathrm{~S} .62(3)$.

${ }^{18}$ Above $\mathrm{n} 2$.
} 
Significantly, the provisions also define what are termed as 'prohibited images', unlike the PCA and CJA offences, which leave the question of whether photographs of children are indecent to the jury, through an application of recognised standards of propriety. ${ }^{19}$ Besides meeting the character requirements stated above, the image must either focus 'solely or principally on a child's genital or anal region', ${ }^{20}$ or portray any of the following acts:

a) the performance by a person of an act of intercourse or oral sex with or in the presence of a child;

b) an act of masturbation by, of, involving or in the presence of a child;

c) an act which involves penetration of the vagina or anus of a child with a part of a person's body or with anything else;

d) an act of penetration, in the presence of a child, of the vagina or anus of a person with a part of a person's body or with anything else;

e) the performance by a child of an act of intercourse or oral sex with an animal (whether dead or alive or imaginary);

f) the performance by a person of an act of intercourse or oral sex with an animal (whether dead or alive or imaginary) in the presence of a child. $^{21}$

Moving or still images produced by any means are caught by the offence, ${ }^{22}$ so this encompasses computer generated images, cartoons and drawings, for

\footnotetext{
${ }^{19}$ See $R v$ Graham-Kerr [1988] 1 WLR 1098.

${ }^{20} \mathrm{~S} .62(6)(\mathrm{a})$.

${ }^{21} \mathrm{~S} .62(7)$.
} 
example. This is where the offence clearly differs from the offence relating to extreme pornographic images under the CJIA, which must be 'explicit and realistic' and consequently would not include cartoons, drawings or paintings. ${ }^{23}$ Moreover, a prohibited image of a child for the purpose of the offence includes 'an image of an imaginary child'. ${ }^{24}$ Therefore, it is made fundamentally clear in the provisions that they will apply to NPPIC that do not depict real children and thus that the child sexual abuse featured in NPPIC does not need to have actual victims.

The same defences are outlined as those available in respect of the offence of possession of indecent photographs of children under the CJA. ${ }^{25}$ The maximum penalty is lower than the CJA offence, being three years' imprisonment on conviction on indictment, in contrast to five years under the CJA. ${ }^{26}$ The reason for this was explained in the Consultation Paper: indecent photographs of children are more harmful to children than NPPIC. ${ }^{27}$ Thus, indecent photographs and pseudo-photographs of children (the latter being photographs that are not real images of child sexual abuse, but may involve the manipulation of a real child's image and tend to be computer-generated) are excluded from the ambit of the

\footnotetext{
${ }^{22} \mathrm{~S} .65(2)(a)$. Or data capable of conversion into an image (s.65(2)(b)).

${ }^{23}$ CJIA, s.63(8); Explanatory Notes, above, n 2, para 459.

${ }^{24}$ S.65(8).

${ }^{25}$ That the individual had a legitimate reason for possessing the image, or that he had not seen the image and had no reason to suspect it was a prohibited image, or that the image was sent to him without any request, and that he did not keep it for an unreasonable time (s.64), and see the CJA, s.160 (2)(a), (b) and (c).

${ }^{26} \mathrm{~S} .66$. The maximum sentence on summary conviction is six months' imprisonment.

${ }^{27}$ Home Office, above n 4, pp 4 and 9.
} 
offence. ${ }^{28}$ From the outset, it would seem that the Government was careful to differentiate between indecent photographs of children and NPPIC, because of the easily verifiable and serious harm caused by the former. ${ }^{29}$ To ensure the law reflects this difference, the offence includes the higher standard of obscenity ${ }^{30}$ and a lower penalty, in comparison with the legislation on indecent photographs of children.

Perhaps the Government noted the course of action taken by the American Federal Government to ensure that virtual child pornography was caught by the law. When the extension of the US Code's child pornography provisions to virtual child pornography failed to withstand constitutional challenge because the Supreme Court held that such images do not bear an intrinsic relationship to the sexual abuse of real children, ${ }^{31}$ Congress added a new obscenity provision to the US Code through the PROTECT ACT 2003. This provision prohibits obscene visual representations (of any kind, including drawings, cartoons, sculptures, or paintings), of the sexual abuse of children which depict minors engaged in sexually explicit conduct. ${ }^{32}$ Therefore, the Government may have chosen to take

\footnotetext{
${ }^{28} \mathrm{~S} .65(3)$. An 'image which forms part of a series of images contained in a recording of the whole or part of a classified work' is also excluded from the ambit of the offence. See s.63.

29 'It is the case that cartoons, drawings and material created entirely by manipulation of computer software do not harm real children in the same way as taking indecent photographs of children...' Home Office, above n 4, p 4.

30 'The material causing concern depicts serious child sexual abuse, going beyond the indecency threshold for photographs which is appropriate where real children are, or appear to be, involved.' Home Office, above n 4, p 5.

${ }^{31}$ See Ashcroft v. Free Speech Coalition 535 US 234 (2002); Ost, above n 10, pp 206-207; K Duncan, 'Child Pornography and First Amendment Standards' (2007) 76 Mississippi Law Journal $677, \mathrm{p} 684$.

${ }^{32} \S 1466 \mathrm{~A}(\mathrm{a})(1)$. See also $\S 1466 \mathrm{~A}(\mathrm{a})(2)$, which criminalises 'an image that is, or appears to be, of a minor engaging in graphic bestiality, sadistic or masochistic abuse, or sexual intercourse, including genital-genital, oral-genital, anal-genital, or oral-anal, whether between persons of the same or opposite sex' and lacks 'serious literary, artistic, political, or scientific value'.
} 
a leaf out of Congress' book, placing NPPIC within the category of obscenity rather than indecency in order to achieve what it would have failed to do through the existing law on child pornography. This might explain the wording chosen by Secretary of State Jack Straw during the second reading of the C\&JB, with reference to the provisions: 'We seek all the time to ensure that what this House and the public regard as obscene, objectionable and extremely pornographic and corrupting is covered by the law... ${ }^{33}$ It is interesting that the Secretary of State elected to focus on moral harms that NPPIC are perceived to cause, and it is to the crucial matter of harm that I now turn.

\section{WHAT EXACTLY IS THE HARM OF NPPIC?}

\section{Morality based arguments}

Rather than focusing on concrete harm in the sense of injury or a setback to someone's interests, morality based rationales for prohibition are premised upon threats to morality, whether this is an individual's personal morality, the moral sensibilities of others, or the shared morality of society. The arguments I consider here primarily involve morality in the first two of these senses, since these are the morality based rationales stated or indicated by the NPPIC offence.

\section{a) Offence to others}

\footnotetext{
${ }^{33}$ Hansard, HC Deb, 26 January 2009: column 37.
} 
The inclusion of the character descriptors of 'grossly offensive' or 'disgusting' for the prohibited image suggests that the wrong caused by possessing NPPIC is offence to others. ${ }^{34}$ Here, I turn to Feinberg's comprehensive analysis of offence to consider whether criminalisation of possessing NPPIC is justified because such behaviour generates disgust and a high level of revulsion. Feinberg presents the following as a principle that would legitimate the criminal law's intervention on the basis of offence: 'It is always a good reason in support of a proposed criminal prohibition that it would probably be an effective way of preventing serious offense (as opposed to injury or harm) to persons other than the actor, and that it is probably a necessary means to that end' ${ }^{35}$ For Feinberg, this liberal offence principle is directed towards wrongful offending, that is, offending which violates the rights of those who are offended. But even though the offence principle is directed at preventing a wrong, it does not provide as persuasive a basis for criminalisation as a principle based on harm, for 'the offended mental state in itself is not a condition of harm. From the moral point of view, considered in its own nature (apart from possible causal linkages to harmful consequences), it is a relatively trivial thing. ${ }^{36}$

To ascertain whether behaviour causing offence can be criminalised through an application of the offence principle, Feinberg suggests that the

\footnotetext{
${ }^{34}$ See also, in the context of the offence of possessing extreme pornography, McGlynn and Rackley, above n 2, p 252.

35 J Feinberg, The Moral Limits of the Criminal Law: Offense to Others (Oxford University Press, 1985), p 1.

${ }^{36}$ Ibid, p 3.
} 
legislator balance the seriousness of the offence against the reasonableness of the behaviour in question. ${ }^{37}$ Certain behaviour may cause an especially serious level of offence. Feinberg presents five characteristics of what he terms 'profound offence': such offence is serious and deep; simply the idea of the behaviour occurring, even in private, causes offence; the behaviour offends the individuals who perceive it, not just their sensory perceptions; since the behaviour violates standards of propriety and moral sensibilities, it offends individuals because they believe it to be wrong; and finally, profound offence tends to be impersonal, that is, the individuals offended do not usually perceive themselves to be the victims of the behaviour. ${ }^{38}$ Given the strength of moral sensibilities towards child sexual abuse and images of such abuse, a strong case could be made that the offence caused by NPPIC meets all these characteristics and is therefore profound offence. Indeed, images would not be prohibited under the provisions unless they are 'grossly offensive'. However, before it can be concluded that this profound offence legitimates criminalisation on the basis of the offence principle, it is also necessary to consider the nature of the behaviour relating to NPPIC that the provisions criminalise.

Crimes relating to offence, outrage and disgust tend to include a public element, or at least some kind of exposure to others, such as the common law offences of outraging public decency ${ }^{39}$ and the statutory offences of public

\footnotetext{
${ }^{37}$ Ibid, chapter 8.

38 Ibid, pp 58-59.

${ }^{39}$ Knuller v DPP (1972) 56 Cr. App. R. 157; $R$ v Gibson [1990] 2 QB 619; $R$ v Hamilton [2007] EWCA Crim 2026.
} 
display of indecent matter ${ }^{40}$ and sending an indecent article through the postal system. ${ }^{41}$ Profound offence could be caused, for instance, if NPPIC were placed on a billboard in a public place, or leaflets including such images were posted through people's letterboxes. ${ }^{42}$ However, the provisions criminalise the private possession of NPPIC. This is an important matter when considering the reasonableness of the behaviour causing offence. The actor could argue, for instance, that the behaviour is important to him because it is an exercise of his individual liberty to possess and look at such images in the privacy of his own home. He might also argue that the freedom to possess NPPIC deters him from committing actual contact offences and thus, that there is a social value to his possession of NPPIC. ${ }^{43}$

But should such potential reasonableness be outweighed by the seriously high level of offence the behaviour causes? The argument would have to be that criminalisation is still justified because it profoundly offends others simply to know that individuals can possess NPPIC, even though they are not presented with these images and do not know where they are being possessed. This, the 'bare knowledge problem', is a matter considered by Feinberg. ${ }^{44}$ Adopting Feinberg's analysis, it is significant that apart from exceptional cases, bare

\footnotetext{
${ }^{40}$ Indecent Displays (Control) Act 1981, s.1(1).

${ }^{41}$ Postal Services Act 2000, s.85(3). I am not including offences relating to indecent photographs of children here. Whilst they exist within a moral framework of indecency, they are aimed at targeting a harm rather than mere offence. See further Ost, above n 10, pp 83-89.

${ }^{42}$ See generally HLA Hart, Law, Liberty and Morality (Oxford University Press, 1963), p 45.

${ }^{43}$ See M Taylor and E Quayle, Child Pornography: An Internet Crime (Hove: Brunner-Routledge, 2003), pp 90-91. The importance of the behaviour to the actor and whether it has a social utility are two standards that Feinberg suggests in order to assess the reasonableness of the offensive conduct (Feinberg, above $n$ 35, pp 37-38).

${ }^{44}$ Ibid, pp 60-71.
} 
knowledge offence does not constitute a wrong to those offended. As Feinberg explains: 'The offended party experiences moral shock, revulsion, and indignation, not on his own behalf of course, but on behalf of his moral principles or his moral regard for [the matter in question]. ${ }^{45}$ Thus, bare knowledge offence does not normally constitute 'wrongful offence', since individuals who are offended do not have their rights violated; they are not the victims of the behaviour. This is clearly the case regarding the possession of NPPIC; it is individuals' moral principles and their moral regard for children that cause them to be profoundly offended by NPPIC, rather than any affront felt because they see themselves as the victims of the behaviour. ${ }^{46}$ This can be contrasted with, for example, homosexual hate speech that occurs in private meetings. As a member of the insulted group, a homosexual individual might herself or himself feel personally offended at the bare knowledge that this speech is occurring in private. ${ }^{47}$ Since bare knowledge offence regarding the private possession of NPPIC is not a wrong to the individuals offended, the offence principle cannot extend to prohibit it, even though the offence caused may be profound. ${ }^{48}$ Therefore, criminalisation of this behaviour can only be justified on the basis of offence if we accept that the criminal law can intervene on the basis of legal

\footnotetext{
45 lbid, p 68.

${ }^{46}$ A possible exception could be profound offence caused to individuals who have themselves been victims of pornography and sexual abuse when they were children, but I do not anticipate that this would normally be the reason why the possession of NPPIC could cause most individuals to experience profound offence.

${ }^{47}$ Feinberg gives the examples of racist mockery and the viewing of abusive adult pornography in a private setting as exceptional cases where bare knowledge offence can wrong the individual offended who is a member of the insulted group. Feinberg, above $n 35, p p$ 69-70.

${ }^{48}$ In the words of Hart: 'a right to be protected from the distress which is inseparable from the bare knowledge that others are acting in ways you think wrong, cannot be acknowledged by anyone who recognises individual liberty as a value.' Hart, above $n$ 42, p 4. See also Mill, above $n$ 13, pp 150, 152, 167.
} 
moralism, ${ }^{49}$ which I have already noted would be at odds with the liberalist tradition..$^{50}$ Not least, this is because criminalising behaviour on the basis of legal moralism is likely to lead to expansive infringements of liberty. ${ }^{51}$

\section{b) Depravity and corruption}

As McGlynn and Rackley have observed in the context of the offence of possessing extreme pornography, the inclusion of the term 'obscene character' in defining what can amount to a pornographic image makes a connection to the OPA. $^{52}$ Thus, the decision as to whether an image is pornographic under the NPPIC offence may be made utilising the OPA's 'deprave and corrupt' test. That is, does the image have a tendency to deprave and corrupt its likely audience? ${ }^{53}$ Indeed, a clear link was made to the OPA in the summary of responses to the Home Office's 2007 consultation: 'It is not our intention to criminalise possession of material... which would not fall foul of the Obscene Publications Act. To that

\footnotetext{
${ }^{49}$ Feinberg, above $\mathrm{n} 35, \mathrm{p}$ 69. The principle of legal moralism is that it is appropriate to prohibit immoral conduct even when it does not cause harm or offence to others; that is, 'victimless' immorality is a matter the law should be concerned with, because it is one of the functions of law to enforce morality.

50 See, for instance, J Feinberg, The Moral Limits of the Criminal Law: Harmless Wrongdoing (Oxford University Press, 1988), p 145. For an absorbing liberal defence of legal moralism, however, see Michael Moore, Placing Blame (Oxford: Clarendon Press, 1997).

${ }^{51}$ When referring to a theory of social rights which would enable all individuals to demand state action against any individual who does not act 'in every respect exactly as he ought' and thus weakens and demoralises society, Mill states that 'so monstrous a principle is far more dangerous than any single interference with liberty; there is no violation of liberty which it would not justify'. Mill, above n 13, pp 158.

52 McGlynn and Rackley, above n 2, p 252.

${ }^{53}$ OPA, s.1. Although I should note that when this paper was at proofs stage, a Ministry of Justice Circular was published in which it is stated that the definition of the concept of 'obscene character' under the new provisions is 'distinct' from the 'technical' definition under the OPA which is 'specifically geared to the concept of publication'. Ministry of Justice, Coroners and Justice Act 2009 (Provisions coming into force on 6 April 2010), Circular 2010/06 (2010), para 18. Whilst this might indicate that the deprave and corrupt test will not be employed, I submit that the OPA test may still be looked to for guidance because obscenity is such an ambiguous concept.
} 
end we envisage the offence having a third element to it, namely that the material caught is of an obscene character. ${ }^{, 54}$ Essentially, the 'deprave and corrupt' test reflects a personal corrupting moral harm argument rather than an 'offence to others' claim. ${ }^{55}$ The harm in question relates to the repercussions of a negative alteration to an individual's moral character, caused by coming into contact with the material in question. ${ }^{56}$ But it is not necessary to establish that the depravity and corruption actually lead to bad conduct. ${ }^{57}$ It is possible to apply this moral harm argument beyond the individual by contending that if the state fails to act against this depravity and corruption, then gradually the moral attitudes of others will also be altered so that we become dessensitised to the material in question and society's shared morals are thus at threat. ${ }^{58}$

The possible utilisation of the depravity and corruption test in the context of the NPPIC offence raises a significant concern. The OPA is directed at the publication and dissemination of obscene material; there must be an audience to deprave and corrupt in order for the person who publishes or otherwise disseminates the material to cause this moral harm. However, the possessor of NPPIC is not committing this moral harm by merely possessing the images for his own purposes. In the context of the NPPIC offence, it is thus necessary to take

\footnotetext{
54 Home Office, Consultation on the Possession of Non-Photographic Visual Depictions of Child Sexual Abuse - Summary of responses and next steps (2008), 11.

${ }^{55}$ See also Feinberg, above n 35, p 171.

${ }^{56}$ Although whether being corrupted constitutes harm to the individual is a contested issue. See J Feinberg, The Moral Limits of the Criminal Law: Harm to Others (Oxford University Press, 1984), $p$ 66. Contrast RP George, Making Men Moral: Civil Liberties and Public Morality (Oxford University Press, 1993), pp 226-227.

${ }^{57}$ DPP v Whyte [1972] AC 849: 'bad conduct may follow from the corruption of the mind... [but] it is not part of the [deprave and corrupt test] that it must induce bad conduct' (per Lord Pearson, at 864).

${ }^{58}$ See P Devlin, The Enforcement of Morals (London: Oxford University Press, 1968).
} 
this moral harm argument one step further than it is taken regarding the OPA offences, and to argue that criminalisation is necessary on the ground that an individual should be prevented from depraving and corrupting himself. This would be an instance of legitimating criminalisation on the grounds of 'moralistic paternalism', along the following lines: 'it is bad (harmful) for a person to have impure thoughts and a depraved character whatever he may think about the matter, and the state has a right to protect him from his own folly by banning the corrupting materials. ${ }^{59}$ But even if the application of moralistic paternalism in this context were acceptable in a liberal society, there is a further difficulty. Would the individual possessor who is the creator of the NPPIC not already be depraved and corrupted by his thoughts before he transfers the image that is in his mind onto paper, or a computer? If so, then it would only be possible to paternalistically protect the possessor who is not the creator of the image from depravity and corruption. However, the House of Lords' judgment in DPP $V$ Whyte may indicate that according to the law at least, it is possible for an individual to be recorrupted. With reference to the OPA, Lord Wilberforce stated that: 'The Act is not merely concerned with the once for all corruption of the wholly innocent; it equally protects the less innocent from further corruption' ${ }^{60}$ Applying this to the creator of the NPPIC, it could be argued that the offence is protecting him from depraving and corrupting himself further by transferring his thoughts into an image. Yet it is questionable whether such further recorruption

\footnotetext{
59 Feinberg, above $\mathrm{n} 35, \mathrm{p}$ 100. Dworkin defines moral paternalism as the claim that we are entitled to interfere with persons on the grounds that they will be (1) in a morally improved state and (2) that such a state will be better for the individual in question.' G Dworkin, 'Moral Paternalism' (2005) 24 Law and Philosophy 301, p 308.

${ }^{60}$ At 863.
} 
actually occurs and, even accepting that it does, that it is a matter for the criminal law, since it does not cause harm to anyone else. ${ }^{61}$

What the above analysis reveals is that the application of a moral harm argument on the basis of depravity and corruption to legitimate criminalising the possession of NPPIC is not straightforward. Furthermore, it should not amount to an appropriate basis for criminalisation unless moralistic paternalism is seen as a persuasive ground for restricting an individual's private behaviour. ${ }^{62}$ And, as with legal moralism, this is not something liberalists would normally accept. ${ }^{63}$

\section{Arguments based on actual and potential harm to children}

Here, Mill's harm principle forms the basis for possible rationalisations of the offence. Thus, the following arguments all revolve around the harm or risk of harm to children that NPPIC might represent. ${ }^{64}$ Whilst I will primarily apply a classical liberal harm based rationale, I will also extend my analysis of harm to a broader liberal humanist rationale.

\section{a) NPPIC that depict real child sexual abuse cause primary harm to children}

\footnotetext{
${ }^{61}$ Unless it causes the creator to go on to commit actual child sexual abuse, but, as I discuss below, there is no proof that viewing child pornography has this effect.

${ }^{62}$ For arguments that it can be perceived as such, see George, above n 56, p 107.

${ }^{63}$ See Mill, above $n$ 13, p 78.

64 'Whenever... there is a definite damage, or a definite risk of damage, either to an individual or to the public, the case is taken out of the province of liberty, and placed in that of morality or law.' Mill, above n 13, p 150.
} 
In the Consultation Paper, the Government discussed the problem of manipulated real photographs of child pornography (photographs which are altered through computer software and made to look like cartoons or drawings). ${ }^{65}$ Significantly, in the case of these particular types of NPPIC, the same justification for criminalisation could be made as regards real images of child pornography, especially if a child is sexually abused in order for the original photographs which become NPPIC to be made. The harm caused by these NPPIC would be the direct harm caused to the child who features in the images. In addition, prohibiting the possession of real images of child pornography can be rationalised because the child suffers further psychological harm from the knowledge that other individuals are looking at the photograph of her being sexually abused. ${ }^{66}$ This could be extended to the possession of NPPIC that are manipulated real photographs of child pornography. But if part of the reason why others' possession of the photograph is psychologically harmful is because the child can be identified (that is, she suffers harm because of the knowledge that others will see a recognisable image of her), then this might depend on how recognisable the manipulated depiction of her is.

Whilst I find this harm based argument to be persuasive because it centres on causing direct harm to children, it is hard to understand why a new offence was necessary to capture such NPPIC. This is because, in 2008, the definition of a

\footnotetext{
${ }^{65}$ Home Office, above $\mathrm{n} 4, \mathrm{pp}$ i and 5.

${ }^{66}$ See $R$ v. Beaney [2004] 2 Cr App R (S) 82, para 9; New York v. Ferber 458 US 747 (1982), 759; Taylor and Quayle, above n 43, p 31.
} 
photograph for the purposes of the offences regarding indecent photographs of children was extended to a tracing or other image which is not itself photographic in nature, but is derived from a photograph or a pseudophotograph. ${ }^{67}$ Consequently, such images were already prohibited under the existing law. What the existing law did not catch were images that depict real child sexual abuse, but are not derived from a photograph or pseudophotograph. Take, for example, a drawing that records the real sexual abuse of a child by an adult. The same harm argument applies to such NPPIC as images created through the manipulation of real photographs. Yet the Government did not present these particular versions of NPPIC as the main material it was targeting. Rather, it was fantasy, completely fabricated images that were generally referred or alluded to in the Consultation Paper. For instance, when outlining the proposed penalty for an NPPIC offence, a lower penalty was put forward than that for possessing indecent photographs of children because NPPIC 'do not depict actual abuse of a real victim' ${ }^{68}$ The case for the offence on the basis of harm would have been much more compelling had it been directed to NPPIC that do depict the actual abuse of a real victim, or depict a real child.

\section{b) If NPPIC depict real children, then harm is caused to these children}

Here, I am concerned with NPPIC that are computer generated and made to look like actual photographs of real children. No child is sexually abused when the image is created, but the fantasy sexual abuse is of a real child. In explicating this

\footnotetext{
${ }^{67}$ S.7(4)) of the PCA, as inserted by the CIIA, s.69.

${ }^{68}$ Home Office, above n 4, p 9.
} 
harm argument, it is useful to draw an analogy with indecent pseudophotographs of children, which are criminalised under the PCA and CJA. ${ }^{69} \mathrm{~A}$ pseudo-photograph can be created through the manipulation of an innocuous photograph of a child by, for instance, taking a computer generated image of an adult having graphic sexual intercourse with a child and superimposing a child's head from a real photograph onto the child's body within the image (what I refer to as a morphed pseudo-photograph). ${ }^{70}$ This image could harm the child if she becomes aware of the morphed photograph and suffers consequential psychological harm. Even if this does not occur very often, provided such harm results in just a few cases, this should suffice as a serious justification for criminalisation of the creation and dissemination of morphed pseudophotographs. ${ }^{71}$ Moreover, a child surely has an interest in not being defamed through her image. ${ }^{72}$ If her image is manipulated and presented in a distorted, injurious way and people who know her see the image and have their perceptions of her negatively altered by it, ${ }^{73}$ then this interest is set back. There must always be some possibility, even if slight, that someone the child knows could come into contact with the morphed pseudo-photograph and link it to the child. To apply this to NPPIC, provided that the image in question is made to look

\footnotetext{
${ }^{69}$ My analysis here is drawn from Ost, above $n$ 10, pp 127-130.

${ }^{70}$ See also M Eneman, AA Gillespie and B Carsten Stahl, 'Criminalising Fantasies: The Regulation of Virtual Child Pornography' (2009), http://www.cse.dmu.ac.uk/ bstahl/publications/2009 Criminalising Fantasies ECIS.pdf, p 4. Last visited 3 January 2010. Such an image would be caught by the PCA and CJA offences provided that it looks like a photograph, or is derived from a photograph (s.7(4A) and (7) of the PCA).

71 'If the harm in question is very great, then a very small likelihood of its occurrence will do.' J Feinberg, above n 50, p 190.

72 See Tolley v. JS Fry \&Sons Ltd. [1931] AC 333.

73 See Youssoupoff v. Metro-Goldwyn Mayer (1934) 50 TLR 581, at 587: an individual can be defamed if others are made to think less of her.
} 
like a realistic actual photograph of a recognisable child, then this harm argument could justify criminalising the creation and dissemination of such images. However, it is less forceful when applied to the possession of NPPIC, since the harm here is more remote. Whilst knowledge that others may want to possess such images might encourage creators to fabricate images of a real child, the possessor is not the individual whose actions cause this child's interest to be set back. ${ }^{74}$ Nonetheless, it may still be possible to find a normative link to primary harm, in the sense that the possessor is underwriting the harm caused to the child by the creator of such NPPIC. ${ }^{75}$

What needs to be borne in mind, however, is that the offence covers NPPIC featuring imaginary children. The harm arguments I have discussed here and in the previous sub-section are only applicable where NPPIC depict real children. Where the image does not depict a real child, then its creation does not cause harm to an actual child. Whilst Mill's harm principle can indeed be expanded and manipulated, ${ }^{76}$ there has yet to be a distortion so overbroad that it could encompass harm to imaginary beings, as it would have to in the context of completely fabricated NPPIC if harm is limited to direct harm caused to the children who feature in the images. ${ }^{77}$

\footnotetext{
74 See D Baker, 'The Moral Limits of Criminalizing Remote Harms' (2007) 10 New Criminal Law Review 370. A remote harm relates to behaviour which is not harmful in itself, but the consequences of the behaviour may be.

${ }^{75}$ See Ost, above n 10, pp 117-118.

${ }^{76}$ See N Persak, Criminalising Harmful Conduct (New York: Springer-Verlag, 2007), pp 44-5; BE Harcourt, 'The Collapse of the Harm Principle' (1999) 90 The Journal of Criminal Law and Criminology 109.

${ }^{77}$ I discuss a broader conception of harm in the next sub-section.
} 
Redesigning and limiting the offence to NPPIC featuring real children or real child sexual abuse so that it better targets direct harm may not be a feasible way forward however; on a practical level, it would be extremely difficult for prosecutions to be brought in cases where it is hard to tell if particular NPPIC do depict the actual abuse of real victims, or depict real children. ${ }^{78}$ One possible way around this would be through the introduction of a defence, as I will discuss in the next section.

\section{c) NPPIC can be used to groom children}

This threat of harm was a particular concern for the Government. In its view: 'The offence is required to protect children. The images can be used as a grooming tool, preparing children for acts of abuse. ${ }^{79}$ Studies have shown that child sex abusers may make use of pornographic images to groom children. ${ }^{80}$ Significantly, the act of showing a child NPPIC would not in itself mean that the individual has committed the offence related to sexual grooming under the Sexual Offences Act 2003 (SOA), unless he meets or arranges to meet the child

\footnotetext{
${ }^{78}$ For the same argument in the context of pseudo-images of child pornography, see Ost, above, n $10, \mathrm{p} 88$.

${ }^{79}$ Coroners and Justice Bill Explanatory Notes (London: Stationery Office, 2009), para 857. See also Home Office, above n 4, p 5; Hansard, HC Public Bill Committee: C\&JB, 3 March 2009: column 488 (Maria Eagle (Parliamentary Under-Secretary of State for Justice)).

${ }^{80}$ See M Elliott, K Browne and J Kilcoyne, 'Child Sexual Abuse Prevention: What Offenders Tell Us' (1995) 19 Child Abuse and Neglect, 579 (14 per cent of the child sex abusers interviewed stated that they used pornography when developing strategies to approach children). See also AA Gillespie, 'Indecent Images, Grooming and the Law' [2006] Criminal Law Review 412, p 413; K Williams, 'Child Pornography Law: Does it Protect Children?' (2004) 26 Journal of Social Welfare and Family Law 245, pp 253-254. For discussion of the 'grooming process' see S Craven, S Brown and E Gilchrist, 'Sexual Grooming of Children: Review of Literature and Theoretical Considerations' (2006) 12 Journal of Sexual Aggression 287; S Craven, S Brown and E Gilchrist, 'Current Responses to Sexual Grooming: Implications for Prevention' (2007) 46 Howard Journal of Criminal Justice 60; Ost, above n 10, pp 32-39 and 70-81.
} 
following a course of sexual grooming. ${ }^{81}$ However, in light of judicial interpretation, the individual would in all likelihood commit the offence of causing a child to watch a sexual act under s.12 of the SOA, which includes causing a child to look at an image of a person engaging in sexual activity. ${ }^{82}$ Furthermore, according to the Consultation Paper, the police tend to find NPPIC alongside indecent photographs of children. ${ }^{83}$ No evidence was put forward during the consultation to suggest that groomers are using NPPIC alone to groom. Since an individual who sexually grooms a child by showing her indecent photographs of children would commit offences under the PCA and the CJA, ${ }^{84}$ then considering the applicability of these and the s.12 offences, the Government is not faced with a situation where other criminal laws would not apply. It is thus hard to make the case that without this offence, harmful behaviour towards children in the form of such grooming would escape the grasp of law.

d) NPPIC encourage the objectification of children as sexual objects and thus advocate child sexual abuse

It is surely arguable that NPPIC promote harmful attitudes towards children. Permitting the possession of such images encourages an acceptance of the

\footnotetext{
${ }^{81}$ S. 15 .

${ }^{82}$ S.12. In $R$ v. Abdullahi [2007] 1 WLR. 225, the Court of Appeal interpreted the requirement under s.12 that the act is carried out for the purpose of sexual gratification to apply to a future intended purpose and thus, provided the individual grooming the child intends to receive gratification from some subsequent behaviour, the offence would be made out.

${ }^{83}$ Home Office, above n 4, p 4.

${ }^{84}$ Showing such a photograph under s.1(1)(b) of the PCA and possession under s.160 of the CJA.
} 
representations of children that they convey: their objectification as sexual objects. $^{85}$ Such objectification can only encourage those who desire to commit actual child sexual abuse. ${ }^{86}$ According to the C\&JB's Explanatory Notes: 'Viewing such images can desensitise the viewer to acts of child abuse, and reinforce the message that such behaviour is acceptable. Banning [their] possession is justified in order to establish clearly and in accordance with the law that it is not. ${ }^{87}$ This mirrors the view of the NSPCC that 'the existence of these images serves to rationalize sexually abusive behaviour towards children in the real world and potentially serves to legitimise it in abusers' minds. ${ }^{88}$

This harm argument has parallels with feminist critiques of adult pornography, such as Kappler's contention that the powerful medium of pornography enables the propagation of sexist, exploitative representations of women to a male audience. ${ }^{89}$ Although the harm of objectification and exploitative representations is not necessarily verifiable, it has been accepted in legal discourses. ${ }^{90}$ In my view, the objectification argument bolsters the case for prohibiting the creation and dissemination of all NPPIC, including completely

\footnotetext{
${ }^{85}$ On objectification, see MC Nussbaum, Sex and Social Justice (New York, Oxford University Press 1999), pp 213-239.

${ }^{86}$ For an expanded discussion of this argument in the context of real child pornography, see Ost, above n 10, pp 105-107.

${ }^{87}$ Explanatory Notes, above $\mathrm{n} 79$, para 861.

88 NSPCC, NSPCC Briefing: Coroners and Justice Bill, (2009), http://www.nspcc.org.uk/Inform/policyandpublicaffairs/Westminster/briefings/CoronersandJusti ce wdf63084.pdf, 3. Last visited 3 January 2010.

${ }^{89} \mathrm{~S}$ Kappeler, The Pornography of Representation (Minneapolis, University of Minnesota Press, 1986), p 52. See also CA MacKinnon, Toward A Feminist Theory of The State (Cambridge, Mass, Harvard University Press, 1991), and the 'cultural harm' argument presented in McGlynn and Rackley, above $\mathrm{n} 2$, p 257.

${ }^{90}$ See the Canadian Supreme Court case of $R v$. Sharpe [2001] SCC 2: 'child pornography may change possessors' attitudes in ways that makes them more likely to sexually abuse children. People may come to see sexual relations with children as normal and even beneficial' (at para 87 (per McLachlin CJ)).
} 
fabricated images which do not directly harm real children through their creation and dissemination, since creators and distributors are actively promoting attitudes that society considers to be harmful. But it is harder normatively to justify criminalising the possession of NPPIC on this basis, because the possessor is not the individual propagating the harmful attitudes. ${ }^{91}$ He would only cause primary harm to children if he goes on to commit actual sexual abuse. In fact, this was a consequence of possessing NPPIC suggested in Parliament:

How can [it be said] for example, that what the [individual] may do with an image that he has conjured up from his imagination in the privacy of his own home as part of a paedophile activity, will not lead to other things? It seems self-evident that if somebody can get gratification from that sort of activity, it may be but a short step towards involving real images of children and real activities. ${ }^{92}$

However, the causative link between viewing pornographic images and committing child sexual abuse is not proven. ${ }^{93}$ In response to this, it could be contended that the possessor indirectly causes harm to children because he is encouraging the market in NPPIC. In the context of virtual child pornography, Wasserman has argued that:

\footnotetext{
${ }^{91}$ See $R v$. Sharpe, ibid, para 100 (per McLachlin CJ).

92 Hansard, HC Public Bill Committee: C\&JB, 3 March 2009: column 480 (George Howarth).

${ }^{93}$ See Ost, above n 10, pp 110-112. See also Eneman et al, above n 70, p.7.
} 
...the sale and possession of virtual child pornography would help maintain the child pornography market, which would leave open the financial conduit by which the creation of all child pornography is funded and would lead to an increased risk that real children would be violated. ${ }^{94}$

For this argument to be convincing, it would need to be established that the knowledge that individuals wish to possess NPPIC encourages creators to create more NPPIC that depict real child sexual abuse, or real photographs of child pornography. Only then would the possessor's behaviour encourage harm to children. A further related line of reasoning is that possessors of NPPIC incite creators of child pornography to abuse children because, through viewing NPPIC, their desire to view real child pornography will be increased and they will thus demand such material from its creators. ${ }^{95}$ But again, there is no empirical proof of this. Indeed, an individual may have sought NPPIC because they were lawful, prior to the new offence coming into force. He may have chosen to avoid real child pornography because he feared the consequences of breaking the law. Perhaps criminalising what was previously lawful might even pose a greater threat to children. This was an issue that troubled MP Jennifer Willott, who was 'concerned that we are legislating without any evidence... If the evidence showed that having images that were not photographic acted as a release, and

\footnotetext{
${ }^{94}$ A Wasserman, 'Virtual.Child.Porn.Com' (1998) 35 Harvard Journal on Legislation 245, p 270.

${ }^{95}$ See, for instance, Hansard, HC Standing Committee B: Criminal Justice and Public Order Bill, 15 February 1994: column 742 (Mike O’Brien).
} 
therefore reduced the risk of harm to children, legislating could increase the risk of harm. ${ }^{96}$

To summarise, the objectification argument may offer a persuasive justification for criminalisation when applied to the creation and dissemination of NPPIC because creators and distributors propagate harmful attitudes. At a normative level, it is more problematic when directed at the individual who possesses NPPIC, unless and until there is empirical proof that the possessor causes direct harm to children. However, I recognise that not all liberals would necessarily demand proof of such direct harm. The harm stemming from objectification - the promotion of harmful attitudes towards children - could be perceived as offering a persuasive justification for criminalising the possession of NPPIC by liberal humanists, even if we cannot establish direct harm. For instance, Martha Nussbaum's account of liberalism is one that cultivates humanity. ${ }^{97}$ That is, she centres the ethics of her approach on concern for others, on compassion, and prioritises the equal importance of each individual in liberalism. ${ }^{98}$ Echoing the Kantian maxim, Nussbaum emphasises that '[e]ach human being should be regarded as an end rather than as a means to the ends of others'. ${ }^{99}$ On this version of liberalism, since the objectification of children that NPPIC promote 'does not take place in a larger context of regard for humanity' ${ }^{100}$ and the images

\footnotetext{
${ }^{96}$ Hansard, HC Public Bill Committee: C\&JB, 3 March 2009: column 481 (Jennifer Willott).

97 MC Nussbaum, Cultivating Humanity: A Classical Defence of Reform in Liberal Education (Cambridge, Mass, Harvard University Press 1997), p 8. A rich analysis of Nussbaum's writings and critique of pornography has recently been provided by C McGlynn and I Ward, 'Pornography, Pragmatism, and Proscription' (2009) 36 Journal of Law and Society 327.

${ }_{98}$ McGlynn and Ward, ibid, pp 338-339; Nussbaum, above n 85, p 10.

${ }^{99}$ Nussbaum, ibid.

100 Ibid, at 238.
} 
depict abuse of the powerless, the possession of NPPPIC could justifiably be criminalised in order to avoid a cultural sanctioning of such abuse. ${ }^{101}$ Although this is a powerful argument for censorship, I am most persuaded by it when it is applied to the creation and dissemination of NPPIC rather than possession. This is because the criminal law should be directed at those who perpetrate harm and as I have argued above, it remains normatively problematic to criminalise the actions of the possessor because any harm he causes is indirect and remote. It is the creators and distributors of NPPIC who are the primary perpetrators of this wider conception of harm and therefore, it is criminalisation of their actions that can be persuasively justified on the basis of a broader version of liberalism such as this one. ${ }^{102}$

\section{REFRAMING THE OFFENCE TO BETTER TARGET HARM}

Following on from the analysis in the preceding section, I propose that there are two ways in which the NPPIC offence could be framed in order to better target the harms such images cause. First, applying a broader conception of harm along the lines of liberal humanism could justify an offence limited to the creation and dissemination of all NPPIC (including completely fabricated images), since this is behaviour which propagates harmful attitudes towards children. It is arguable that this broader interpretation of harm can be extended to justify criminalising

\footnotetext{
${ }^{101}$ McGlynn and Ward, above n 97, p 342 and see p 341.

102 Although I have argued that criminalisation of possession can be justified on the basis that possessors are reinforcing the primary harm caused by creators/distributors (see above, $n$ 75), it is much more problematic to apply this in the context of completely fabricated NPPIC.
} 
behaviour that causes indirect, more remote harm to children, such as the possession of fantasy images. But in my view, this is too much of a distortion of the harm principle and criminalising the possession of NPPIC on this basis is harder to defend at a normative level.

So why did the Government elect to move straight to criminalising the possession of NPPIC, rather than targeting creation and distribution? Clues may be gleaned from the history of the legislation on indecent images of children. The law was first directed towards the creation and dissemination of these images under the PCA, before mere possession was subsequently criminalised under the CJA. Prior to the enactment of the CJA, police officers had called for the possession of indecent photographs of children to be criminalised since prosecutions could not be brought in some cases where material was found, but evidence of intended distribution was lacking. ${ }^{103}$ This may reveal something of the motivation for targeting possession in the context of NPPIC - possession is the easiest offence to prove. ${ }^{104}$ Certainly, the Government anticipated that a possessing NPPIC offence would catch behaviour not currently criminal under existing law. As stated in the C\&JB's Explanatory Notes:

The publication of such material could already contravene the Obscene Publications Act 1959. However, the use of the internet has meant that

\footnotetext{
${ }^{103}$ See 'Yard officers seek more help to fight child pornography', The Times, 4 April 1988; 'Labour backs Hurd on child pornography', The Times, 17 October 1987; 'Obscenity call', The Times, 8 October 1987. See also Williams, above n 80, p 256.

${ }^{104}$ See generally MD Dubber, 'The Possession Paradigm: The Special Part and the Police Power Model of the Criminal Process', in RA Duff and SP Green (eds.) Defining Crimes: Essays on the Criminal Law's Special Part (Oxford University Press, 2007) 91, p 96.
} 
controls on the circulation of this material are easier to by-pass as sources may be from outside the UK or in circumstances where prosecution for publication is not feasible. As a result this material has a potentially wide public circulation. ${ }^{105}$

The new offence was thus perceived to offer a more effective means of tackling the circulation of NPPIC because prosecutors will not have to prove that an individual published such an image, but merely that it is in his possession and he knows this to be the case. ${ }^{106}$ As should be apparent from the discussion above, however, the fact remains that when behaviour does not in itself involve the creation of material that depicts actual child sexual abuse, or the dissemination of harmful or otherwise objectionable material, the matter of harm is less apparent. Furthermore, it appears that the Government's main target was the circulation and downloading of NPPIC from the internet. During the Committee Stage in the House of Commons, Maria Eagle (Parliamentary Under-Secretary of State for Justice) stated: 'We need the possession offence because we are talking about the internet ... Possession offences are a way of trying to control these images when the internet is the main means of distribution; otherwise we shall not have any control over them.'107 Yet control over the publication of obscene images on the internet has been extended as a consequence of case law which

\footnotetext{
${ }^{105}$ Explanatory Notes, above $\mathrm{n} 79$, para 855.

106 In Atkins V DPP [2000] 1 WLR 1427, the Court of Appeal held that the offence of possessing indecent photographs of children was not made out where images viewed on the internet had been stored in the computer's cache without Atkins' knowledge. See also $R v$ Collier [2005] 1 WLR 843.

${ }^{107}$ Hansard, HC Public Bill Committee: C\&JB, 3 March 2009: column 484. See also Eneman et al, above $\mathrm{n} 70$, pp 2 and 7.
} 
has established that for the purposes of a prosecution under the OPA, the major steps in relation to publication do not have to take place within this jurisdiction. According to the Court of Appeal judgment in $R v$. Perrin, ${ }^{108}$ material is published for the purposes of the OPA when it is accessed in this jurisdiction. It is still necessary, however, for the publisher to be within this jurisdiction. ${ }^{109}$ But even if more control of the circulation of images on the internet is required, an offence of possessing NPPIC was arguably still not necessary. If the individual has knowledge of the content of the NPPIC, viewing and downloading such images from the Internet would have been caught by an offence of creating NPPIC, provided that judicial interpretation in cases involving indecent photographs of children were to be followed. ${ }^{110}$

Notwithstanding this, the argument could still be made that a possession offence may be the only means of tackling the evils of creation and dissemination which the police cannot detect. Bearing this in mind, the second alternative way in which the offence could be reframed would be to retain it as a possession offence, but to include a defence if the defendant establishes that the image was completely fabricated. ${ }^{111}$ This would be a preferable option to simply restricting the ambit of the offence to NPPIC that depict the actual abuse of real victims or depict real children, because of the practical difficulty I alluded to in

\footnotetext{
108 [2002] EWCA Crim 747.

${ }^{109}$ See J Rowbottom, 'Obscenity Laws and the Internet: Targeting the Supply and Demand' [2006] Criminal Law Review 97, p 99.

${ }^{110}$ See $R$ v. Smith, $R$ v. Jayson [2002] EWCA Crim. 683; Y Akdeniz, Internet Child Pornography and the Law: National and International Responses (2008), 50-1 and 55-57; Ost, above n 10, pp 55-56. ${ }^{111}$ See also SL Friel, 'Porn by Any Other Name? A Constitutional Alternative to Regulating "Victimless" Computer-Generated Child Pornography', (1997) 32 Valparaiso University Law Review 208, p 258.
} 
the previous section. That is, it would be extremely difficult for the prosecution to establish that the particular NPPIC features a real child or real child sexual abuse. Instead, the introduction of a defence would have the following effect: in a case where the defendant proves the image was completely fabricated, he will not have committed the offence notwithstanding that the prosecution can prove the possession element and that the NPPIC meets the character requirements of the offence. This is placing a legal rather than an evidential burden on the defendant; if the defendant fails to establish the image was completely fabricated on the balance of probabilities, then, to utilise Dennis' wording, he assumes the risk of being convicted. ${ }^{112}$ It is to be contrasted with a defence that places an evidential burden on the defendant, such as him having to provide sufficient evidence to raise an issue regarding the image being completely fabricated since here, the burden remains on the prosecution. In the context of NPPIC, the latter formulation of the defence is problematic as it would produce the same practical difficulty for the prosecution in establishing that the particular NPPIC features a real child or real child sexual abuse.

The difficulty with placing the legal burden on the defendant, however, is that this could run afoul of the presumption of innocence under Article 6(2) of the European Convention on Human Rights $(\mathrm{ECHR}){ }^{113}$ Although the right protected under Article 6(2) is not absolute, in order for a provision imposing a

\footnotetext{
112 I Dennis, 'Reverse Onuses and the Presumption of Innocence: In Search of Principle' [2005] Criminal Law Review 901, p 904; M Blake and A Ashworth, 'The Presumption of Innocence in English Criminal Law' [1996] Criminal Law Review 314.

${ }^{113}$ Dennis, ibid; P Roberts, 'Drug Dealing and the Presumption of Innocence: The Human Rights Act (almost) bites' (2002) 6 International Journal of Evidence and Proof 17.
} 
legal burden on the defendant to be an acceptable qualification of the right, the provision must serve a legitimate aim and be proportionate. ${ }^{114}$ Establishing that the offence is in pursuance of a legitimate aim should be relatively straightforward considering that the goal of criminalising NPPIC through the reframed offence is to avoid harm to children, applying the analysis of harm above. ${ }^{115}$ The matter of proportionality is a harder nut to crack, but there are a number of arguments that can be raised to suggest that reversing the legal burden in this way can be viewed as proportionate.

First, since the prosecution still has to prove the essential facts in issue (that the NPPIC meets the character requirements and that the defendant is in possession of the image), placing the burden of proof on the defendant regarding the matter of whether the NPPIC is completely fabricated may well be proportionate. ${ }^{116}$ Secondly, precedent indicates that if it is difficult for the prosecution to prove the relevant matter in the absence of a presumption of blameworthiness, this may be important when determining whether the imposition of a legal burden on the defendant is justifiable and proportionate. For instance, in $R v$ Lambert, Lord Steyn referred to real difficulties for the prosecution posed by sophisticated drug smuggling techniques which would make it hard to prove that the person in possession of a container was aware of the contents. Objective justification for some interference with the burden of

\footnotetext{
${ }^{114}$ See $R$ v Lambert [2001] 3 WLR 206, para 88.

${ }^{115}$ See generally Dennis, above $\mathrm{n} 112, \mathrm{p}$ 909-910.

${ }^{116}$ Attorney-General for Hong Kong v Lee Kwong-kut [1993] AC 951, at 969: 'If the prosecution retains responsibility for proving the essential ingredients of the offence, the less likely it is that an exception will be regarded as unacceptable.' (Per Lord Woolf, at 969.)
} 
proof could therefore be found. ${ }^{117}$ In the case of NPPIC, it would equally be difficult to ensure successful prosecution unless the defendant bears the burden; the sophisticated level of computer generated imagery and image manipulation technologies that can be used could make it impossible for the prosecution to determine the origin of the NPPIC in question. ${ }^{118}$ Thirdly, the offence carries a lower sentence than offences featuring in other cases where the legal burden placed on the defendant was held to be incompatible with Article 6(2). ${ }^{119}$

I realise that it will be difficult for the possessor who is not the creator of the image to prove on the balance of probabilities that it is completely fabricated. But in possessing NPPIC obtained from the internet, for example, he is engaging in blameworthy behaviour by taking the risk that the images do depict real children or real child sexual abuse. ${ }^{120}$ He should thus bear the responsibility for taking that risk. It is possible to draw an analogy here with the case of $R v$ Matthews ${ }^{121}$ and the imposition of a legal burden for an offence involving presumptively blameworthy conduct. According to Dennis' analysis: 'If the parameters of the offence define conduct which is presumptively blameworthy a reverse onus provision which requires the defendant in effect to

\footnotetext{
${ }^{117} R v$ Lambert, at para 36; Dennis, above $\mathrm{n} 112$, at 918.

${ }^{118}$ BBFC, Home Office Consultation: On possession of non-photographic visual depictions of child sexual abuse: The response of the British Board of Film Classification (2007), http://www.bbfc.co.uk/downloads/pub/Public\%20Statements/, at para 10 . Last visited 5 December 2009. See also Eneman et al, above n 70, p 1.

${ }^{119}$ Consider, for example, that the Law Lords were especially concerned in $R v$ Lambert that the maximum sentence for one of the offences under the Misuse of Drugs Act 1971 to which the defence in question (imposing a legal burden) applied was life imprisonment. See paras 38 and 156.

${ }^{120}$ See also Clare McGlynn's response to Home Office's Consultation on the proposed offence, at paras 2.3.1 and 2.3.3, http://www.dur.ac.uk/resources/law/research/Child Porn Consult Response.pdf. Last visited 3 January 2010.

${ }^{121}$ [2003] 3 WLR 693.
} 
rebut the presumption by proving matters of exculpation may be justifiable. ${ }^{122}$ In Matthews, the offence in question was that of possessing a knife in a public place under s.139 of the CJA. The defendant relied on the defence under s.139(4) that he had good reason for having the knife, but he was convicted. On his appeal against conviction, it was held by the Court of Appeal that the defence imposed a legal burden on the defendant, but that this was justifiable notwithstanding its inroad into the presumption of innocence. To draw the parallel with possessing NPPIC, being in possession of a knife in a public place is criminalised to prevent a risk of harm to others. Therefore, carrying a knife in a public place is presumptively blameworthy because one is creating a risk of such harm and the defence offers the defendant the opportunity to demonstrate that his conduct was not blameworthy. ${ }^{123}$ Further, according to Field J, 'the reason for which an accused has a bladed article in a public place is something peculiarly within the knowledge of the accused. We are accordingly quite satisfied that there is an objective justification for some derogation from the presumption of innocence. $^{124}$ If the possessor of an NPPIC is the creator of the image then similarly, he may have peculiar knowledge of whether the NPPIC is completely fabricated, if the technology he has used to create the NPPIC makes it difficult or impossible for anyone else to determine its origins. Although a possessor who is not the creator of the image will lack such peculiar knowledge, if he chooses to possess the NPPIC regardless of not knowing its origins, then he is running the

\footnotetext{
${ }^{122}$ Dennis, above $\mathrm{n} 112$, p 922.

123 Ibid.

${ }^{124}$ At para 16 per Field J.
} 
risk of harm that the offence targets and thus the burden of proving otherwise should arguably rest with him.

Redrafting the offence to include a defence along the lines I am proposing here can be distinguished from other cases where Parliament has put a legal burden on the defendant to prove something the prosecution would otherwise have to prove. What I am suggesting is that Parliament should have limited the offence by putting a legal burden on the accused - if he loses, he is in no worse a position than the position he would be in under the new offence as drafted by Parliament. If he succeeds, then he is not guilty when he otherwise would have been guilty under the new offence. To put it another way, all the ingredients of the offence of possessing NPPIC are provided in the offence itself. Introducing the defence puts a defendant who has proof that the NPPIC is completely fabricated in a more favourable position. ${ }^{125}$ Further, and as a final point here, I am suggesting the introduction of such a defence to reduce the risk of overcriminalisation.

\section{THE PROBLEMATIC ELEMENTS OF THE NEW OFFENCE}

I now turn my analysis to the more specific, problematic elements of the new offence. The way in which the offence will operate and whether it can tackle the mischief it was designed to target is largely dependent on the way it is framed

\footnotetext{
${ }^{125}$ See Lord Rodger's judgment in Sheldrake v DPP [2005] 1 A.C. 264, at paras 68-69 and 71.
} 
(and contained) in the statute, and subsequent judicial interpretation. Unfortunately, there are a number of problematic elements within the provisions. Turning first to the definition of the character of NPPIC as 'grossly offensive, disgusting or otherwise of an obscene character', this wording is identical to that under the CJIA's possession of extreme pornography offence, ${ }^{126}$ and clearly evidences a morality based justification for criminalisation. The harm, or objection to NPPIC, is framed in a morality discourse and, as McGlynn and Rackley note, these terms are 'highly subjective and vague'. ${ }^{127}$ Notwithstanding this, it is arguable that, given the moralistic climate regarding images which depict child sexual abuse, NPPIC would automatically be construed as 'grossly offensive' and 'disgusting' because of their depiction of the acts listed in the offence, or their focus on a child's genital or anal area for the purpose of sexual arousal. Indeed, during the Committee stage of the C\&JB in the House of Commons, MP George Howarth commented that: 'No reasonable person doubts that the sorts of things set out in [the offence] are revolting. They arouse our understandable and natural personal distaste and revulsion. ${ }^{128}$ Therefore, by their very nature, NPPIC are likely to necessarily meet the character requirements. This begs the question of how effective the character requirements will actually be in limiting the reach of the offence to images depicting 'serious child sexual abuse', the material that the Government

\footnotetext{
${ }^{126} \mathrm{CJIA}, \mathrm{s} .63(6)(\mathrm{b})$.

${ }^{127}$ McGlynn and Rackley, above n 2, p 252. For a similar argument in the context of indecency law, see M Childs, 'Outraging Public Decency: The Offence of Offensiveness' (1991) Public Law 20. The NPPIC offence can also be critiqued because, if society considers the primary harm of child pornography to be that caused to the children involved, then the offence is framed around the wrong harm - a moral harm relating to offence, disgust and obscenity. In presenting the harm as moral, the offence arguably underplays the harm to children that NPPIC depicting real child sexual abuse, or featuring real children can cause.

${ }^{128}$ Hansard, HC Public Bill Committee: C\&JB, 3 March 2009: column 485.
} 
originally envisaged it would catch, ${ }^{129}$ especially given the inclusion of images that do not portray such abuse. ${ }^{130}$

Such images will fall under the first content definition of a prohibited image, which does not relate to images which portray certain acts or behaviour, but rather, images which focus solely or principally on a child's genitals or anal region. The question of whether such images have been created solely or principally for the purpose of sexual arousal may be harder for the jury to ascertain. ${ }^{131}$ It is pertinent here to look to similar definitions under the American and Canadian legislation on child pornography. Under the Canadian Criminal Code, a visual representation can be defined as child pornography if its 'dominant characteristic... is the depiction, for a sexual purpose, of a sexual organ or the anal region' of a child. ${ }^{132}$ Material caught by American federal child pornography law includes images which feature the lascivious exhibition of the genitals or pubic area of a minor. ${ }^{133}$ Both of these definitions have been critiqued, since they require scrutiny of images featuring a naked child in order to ascertain whether the focal point of the image is the genital area, for the purposes of sexual arousal. Referring to the American law, Adler has commented that: 'The law requires us to study pictures of children to uncover their potential sexual meanings, and in doing so, it explicitly exhorts us to take on the

\footnotetext{
${ }^{129}$ Home Office, above n 4, p 5.

${ }^{130}$ S.62(6).

${ }^{131}$ That this question is a matter for the jury is made clear in the Explanatory Notes, above $\mathrm{n} 79$, para 355.

${ }^{132}$ Canadian Criminal Code, s.163.1(1)(a)(ii). The broad term 'visual representation' means that these provisions catch NPPIC besides real photographs of child pornography (see S.163.1(1)(a)).

133 US Code, § 2256(2)(A).
} 
perspective of the pedophile. ${ }^{134}$ The danger inherent within such an approach is that any image of a naked child becomes suspect, leading to the sexualisation of the child's naked body. This is potentially damaging to children and to artistic freedom of expression. ${ }^{135}$

The definition under the offence, when read alongside the requirement that the image must have been created solely or principally for the purpose of sexual arousal, may catch fewer images than the definitions under Canadian and American law, due to the inclusion of the words 'solely' or 'principally'. The offence should thus exclude images depicting the entire body of a naked child, since such images would not focus solely or principally on the child's genital or anal region. This would depend, however, on how broadly or narrowly the word 'principally' is interpreted. Take, for example, a computer generated image depicting a child whose upper body is clothed, but her genital area and legs are unclothed. ${ }^{136}$ Would this be an image that focuses principally on the child's genital area? And if so, how would it be ascertained that it has been created solely or principally to sexually arouse? The context in which the image is possessed, even if it is possessed alongside indecent photographs of children, does not necessary establish that it was created for this purpose. Here arguably,

\footnotetext{
${ }^{134}$ A Adler, 'The Perverse Law of Child Pornography' (2001) 101 Columbia Law Review 209, p 256. For a similar critique of Canadian law, see RJ Danay, 'The Danger of Fighting Monsters: Addressing the Hidden Harms of Child Pornography Law' (2005) 11 Review of Constitutional Studies 151, pp 158-159.

135 See A Higonnet, Pictures of Innocence: The History and Crisis of Ideal Childhood (London: Thames and Hudson, 1998), pp 161-2.

${ }^{136}$ Such as, for instance, one of the images that featured in the Canadian case of $R v$ Nedelec [2001] BCSC 1334, of a child sat on the floor with her nightgown up and around her waist and her genital area in view (although here, the image was a photograph rather than a computer generated image).
} 
we would have a situation where images have to be scrutinised to uncover a possible sexual meaning. This may well encourage the same potentially damaging attitude towards the depiction of children's naked bodies as in the US and Canada.

Another question is whether an image would have to depict the nude genital or anal region of a child to fall within the ambit of the offence. In the case of US $v K_{n n o x}{ }^{137}$ the Court of Appeals for the Third Circuit was required to consider whether video footage of girls aged between ten and seventeen, dancing and striking provocative poses and dressed in bathing costumes, leotards and underwear amounted to images featuring the lascivious exhibition of the genitals or pubic area of a minor. It was held that 'lascivious exhibition' meant 'a depiction which displays or brings forth to view in order to attract notice to the genitals or pubic area of children, in order to excite lustfulness or sexual stimulation in the viewer'. ${ }^{138}$ The Court concluded that the genital area did not need to be nude or partially nude to be shown or displayed, and that judicial precedent did not demand a nudity requirement. ${ }^{139}$ The English offence does not state that NPPIC must depict nude children and consequently, if it is interpreted in the same way as the US provisions, the range of material that could potentially fall under the definition of a 'prohibited image' becomes even more expansive. Although the grossly offensive/disgusting/obscene criterion would still need to

\footnotetext{
${ }^{137}$ US v. Knox 32 F.3d 733 (1994).

${ }^{138}$ At 745 (per Cowen J).

${ }^{139}$ See US v. Dost F.Supp. 828 (S.D.Cal.1986), in which a multi-factor list was articulated that can assist American courts in ascertaining whether an image constitutes the lascivious exhibition of a minor's genitals or pubic area. This list (the Dost test), does not include a nudity requirement.
} 
be met, it may not prove to be difficult for a jury to conclude that such an image could meet this criterion, given the strength of moral feeling and public revulsion towards the sexual depiction (or perceived sexual depiction) of children that I alluded to above.

Where does all this leave genuine works of art? The DPP was present to answer questions on the NPPIC provisions during part of the Committee Stage of the C\&JB in the House of Commons. When asked what the situation would be regarding works of art, he responded:

In so far as there are artistic considerations, they are obviously recognised. These provisions will inevitably fall within the framework of article 10 of the European Convention on Human Rights and therefore, in so far as any interpretation is needed to comply with article 10 , that will be done by the courts in due course. That, I anticipate, will enable defences to be run that are consistent with article $10 .^{140}$

But given the implication from the DPP's response that artistic considerations may well arise, why there is no specific defence within the actual provisions? It was stated in the Consultation Paper that 'It is not [the Government's] intention to capture genuine works of art' and that the legitimate reason defence would apply in such cases. ${ }^{141}$ However, according to the Explanatory notes to the C\&JB, this defence covers 'those who can demonstrate that their legitimate business

\footnotetext{
${ }^{140}$ Hansard, HC Public Bill Committee: C\&JB, 5 February 2009: columns 103-4.

${ }^{141}$ Home Office, above n 4, pp 1 and 9.
} 
means that they have a reason for possessing the image $;{ }^{142}$ no reference is made to art. Without the availability of an appropriate defence, it seems, therefore, that artistic freedom of expression is constrained by the offence, unless a successful challenge is brought on the basis of a violation of Article 10 of the ECHR. Whilst it is possible that the character requirement that the image be pornographic may mean that genuine art will be excluded from the ambit of offence, ${ }^{143}$ there is no clearly defined boundary between pornography and art. ${ }^{144}$ A solution to this problem could have been provided had a public good defence been included, as proposed by the British Board of Film Classification (BBFC) in response to the Home Office Consultation. ${ }^{145}$ The BBFC was especially troubled by the potential inclusion of historic artefacts 'including drawings, sculptures, and pottery from Ancient Rome or Greece, which contain non-photographic images of characters who appear to be children engaged in various forms of sexual activity'. Such items may have originally been created for pornographic purposes, but there is a clear reason for excluding them from the offence on the basis of the public good. ${ }^{146}$

\footnotetext{
${ }^{142}$ Explanatory Notes, above $\mathrm{n} 79$, para 368. See also Coroners and Justice Act Explanatory Notes (London: Stationery Office, 2009), para 377.

${ }^{143}$ Home Office, above, n 54, 10: 'This [pornographic] test is intended to eliminate, for example, works of art... which are of public interest'.

${ }^{144}$ As McGlynn and Ward ask: 'What is pornographic and what is not?' McGlynn and Ward, above n 91, p 331. See also McGlynn, above, n 120, para 6.2; BBFC, above, n 118, paras 4 and 5; Home Office, ibid, 8 . And of course, the same question can be asked in respect of art. See Home Office, ibid, 17-18.

${ }^{145} \mathrm{BBFC}$, above, $\mathrm{n}$ 118. See also McGlynn above, n 120, paras 6.4.1 and 6.5. Home Office, above, n 54,8 and 9.

${ }^{146}$ BBFC, ibid, para 7. See also 'Graphic artists condemn plans to ban erotic comics' The Independent 23 March 2009.
} 
The very wide ambit of material that may be caught by the offence was an issue of concern for MP Jenny Willott during the C\&JB's Committee Stage in the House of Commons. Highlighting the broad nature of the definition of an image as a moving or still image (produced by any means), she asked the DPP whether her behaviour would be criminalised under the offence if she scrawled a pornographic image on a piece of paper. ${ }^{147}$ The DPP 'anticipate[d] that it would be. ${ }^{148}$ Moreover, the definition of an image is made even broader because the image does not have to be realistic, unlike material caught by the possession of extreme pornography offence.

Furthermore, the NPPIC offence does not just encroach on freedom of expression but also the right to privacy, given that possession tends to be a private act. Indeed, whilst the C\&JB was going through its parliamentary stages, questions were raised about the human rights implications of the proposed offence. The Human Rights Joint Committee was not convinced that the potential violation of Articles 8 and 10 could be justified, highlighting the offence's potential subjectivity, its lack of precision and the Government's failure to explain why it was necessary to meet the aims specified and how it was proportionate to those aims. ${ }^{149}$ However, in the Government's view, the state could rely on the exceptions under part 2 of Arts 8 and 10 of the European Convention on Human Rights to justify the offence, and the interference with privacy and freedom of expression it is likely to cause:

\footnotetext{
${ }^{147}$ Hansard, HC Public Bill Committee: C\&JB, 5 February 2009: column 105.

148 Ibid.

149 Human Rights Joint Committee, Eighth Report. Legislative Scrutiny: Coroners and Justice Bill (London: Stationery Office, 2009), para 1.172.
} 
[S]uch interference is plainly justified. It is intended to achieve a legitimate aim and is necessary to meet that aim. The provisions are a proportionate response to a pressing social need and any consequent interference with Convention rights would be in accordance with the law, and necessary in a democratic society for the prevention of crime, for the protection of morals, and for the protection of the rights and freedoms of others. ${ }^{150}$

It seems likely that reliance on the protection of morals to justify state interference with Articles 8 and 10 would be accepted since, in the context of Article 10, the European Court of Human Rights has held that domestic states have a wide margin of appreciation regarding what state intervention is considered necessary to protect morals. ${ }^{151}$ But there could be grounds to challenge reliance on the protection of morals exception since the Government failed to provide any real assessment of the rationale for invoking morality based arguments in the context of the offence. In Handyside $v$ UK, the European Court of Human Rights emphasised that: 'The domestic margin of appreciation... goes hand in hand with a European supervision... Such supervision concerns both the aim of the measure challenged and its "necessity"..."152

\footnotetext{
${ }^{150}$ Explanatory Notes, above $\mathrm{n} 79$, para 859

${ }^{151}$ Handyside v UK (1976) 1 EHRR 737).

${ }^{152} \mathrm{lbid}$, at 754 (emphasis added).
} 
Even assuming that reliance on the protection of morals exception is successful, if the Government's aim was truly to protect children from harm, should reliance not primarily be based on the offence being necessary to protect the rights and freedoms of others? As should be apparent from the analysis in this paper, I am not convinced that this exception is applicable on the basis of the Government's rationale for introducing the offence. I submit that the State would have had a much stronger case for relying on the exception under Article 8 relating to the protection of rights and freedoms of others if it had directed the offence to NPPIC depicting real child sexual abuse, or featuring real children by means of including a defence regarding completely fabricated images. Then, reliance could have been placed on the harm that may be caused to children, the violation of their rights that possessing such NPPIC could amount to. Whilst the creation and dissemination of such NPPIC would arguably impinge on children's rights and freedoms more greatly than possession, the state could argue that possession causes further psychological harm to the child who is aware that others are looking at a visual depiction of her sexual abuse (or what appears to be such). Alternatively, working on the basis of a broader conception of harm, the state could have had convincing grounds for relying on the same exception under Article 8. The harm at issue here would be that caused by the objectification of children in NPPIC (including completely fabricated images), and their encouragement of harmful attitudes towards children. But in my view, on this version of harm, an offence relating to creation and distribution would be more proportionate to the aim of protecting the rights and freedoms of others 
than one of possession, since the possessor is not propagating the harmful attitudes.

There is a further right under the ECHR which the NPPIC offence may violate. Article 7, an absolute right, provides that 'No one shall be held guilty of any criminal offence on account of any act... which did not constitute a criminal offence under national or international law at the time when it was committed.' It has been recognised that the principle of legal certainty underlies this right, ${ }^{153}$ a principle that, for practical reasons, is one of maximum certainty rather than absolute certainty. ${ }^{154}$ Case law suggests that uncertainty posed by one particular element of an offence is not problematic provided it forms part of a more comprehensive definition of criminalised behaviour. ${ }^{155}$ However, I have alluded to the vague and subjective nature of the NPPIC character requirements and the broad range of material that could fall under the term 'prohibited image'. The uncertainty of definition thus goes far beyond one element of the NPPIC offence. According to the Human Rights Joint Committee:

Criminal offences should be drafted in clear and accessible terms to ensure that individuals know how to regulate their conduct. We remain concerned at the broad definition of the offence and, as a result, its

\footnotetext{
${ }^{153}$ Kokkinakis $v$ Greece (1994) 17 EHRR 397, at 423, para 52: '[Article 7 embodies] the principle that only the law can define a crime and prescribe a penalty (nullum crimen, nulla poena sine lege ) and... it follows from this that an offence must be clearly defined in law. This condition is satisfied where the individual can know from the wording of the relevant provision and, if need be, with the assistance of the courts' interpretation of it, what acts and omissions will make him liable.'

${ }^{154}$ See A Ashworth, Principles of Criminal Law (Oxford University Press, $6^{\text {th }}$ edn, 2009), p 66.

${ }^{155}$ See Hashman and Harrup v UK (2000) 30 EHRR 241 at 258, para 39 and Ashworth, ibid, p 65.
} 
potential application beyond the people whom the Government is seeking to target. ${ }^{156}$

Not only is it difficult to justify the offence on the basis of the classical liberal harm principle, therefore, the Government has drafted an offence with expansive, ill-defined descriptors which may well violate human rights and that could lead to the inclusion of a wide range of material in the ambit of criminalisation.

\section{CONCLUSION}

The purpose of the C\&JA is to establish more effective, transparent and responsive justice and coroner services for victims, witnesses, bereaved families and the wider public' and in part, it seeks to achieve this by 'updating parts of the criminal law to improve its clarity, fairness and effectiveness'. ${ }^{157}$ Quite how extending the reach of the criminal law to capture NPPIC is related to this purpose is unclear, to say the least. A sceptic might wonder whether the C\&JB offered the Government an opportunity to quietly introduce a proposal that would undoubtedly have attracted more publicity had it appeared alongside and at the same time as other provisions that highlight the increased criminalisation of the possession of pornographic material, such as the recent offence relating to

\footnotetext{
${ }^{156}$ Human Rights Joint Committee, above n 149, para 1.174.

${ }^{157}$ Explanatory Notes, above n 79, para 15.
} 
extreme adult pornography. As colourfully expressed by MP David Howarth in reference to the C\&JB:

[A] principle of legislative drafting that the Bill seems to follow is that of the red rag and the smuggle. A red rag is a provision in a Bill that is designed to attract the attention of hot-headed Members of this House, and about which the Government do not, in reality, care very much either way, while they smuggle in, largely unnoticed and unchallenged, a lot of significant stuff that otherwise might attract severe criticism. ${ }^{158}$

There is a crucial difference between, on the one hand, real child pornography that depicts the actual sexual abuse of children and, on the other, completely fabricated images that do not cause harm to an actual child. According to a spokesperson for the Children's Charity NCH, speaking in 2008, the Government's move to criminalise NPPIC 'makes a clear statement that drawings or computergenerated images of child abuse are as unacceptable as a photograph'. ${ }^{159}$ । contend that perceiving fantasy NPPIC to be as unacceptable, or indeed, as harmful as images of real pornography, seriously underplays the physical and psychological damage that children who feature in real child pornography suffer. The harm caused by real child pornography is concrete and undeniable. In contrast, the harm caused by NPPIC is much less verifiable and no attempt to

\footnotetext{
${ }^{158}$ Hansard, HC Deb, 26 January 2009: column 61. For parliamentary criticism about the size of the Bill, and the inclusion of too many subjects, see Hansard, HC Public Bill Committee: C\&JB, 3 March 2009: columns 3 and 4; Hansard, HL Deb, 18 May 2009: columns 1209, 1210, 1223, 1225, $1248,1252,1261,1270,1276,1288-9$ and 1292.

159 'Computer generated abuse "banned"', BBC News report, 28 May 2008, news.bbc.co.uk/go/pr/fr/-/1/hi/uk/7422595.stm. Last visited 3 January 2010.
} 
measure harm was made by the Government prior to the introduction of the proposed offence in the C\&JB. Indeed, the Human Rights Joint Committee concluded that:

The Government has stated that the offence is needed to protect children and vulnerable adults and to fill a gap in the law. However... it has provided no concrete evidence to demonstrate the need for the new offence. We reiterate our view... that legislation should be evidencebased. Such evidence should be published in time to assist parliamentary scrutiny. Whilst we fully support appropriately targeted criminal offences which will [protect] children from abuse, itself a gross violation of their human rights, we are disappointed that the Government has failed to provide sufficiently weighty reasons for the need of the new offence... ${ }^{160}$

Couple this with the Government's prediction that the number of prosecutions under the offence will be low, ${ }^{161}$ and the perceived justification for its introduction may become even more questionable. However, if the possession of NPPIC does cause significant harm, then the fact that the offence will not be frequently utilised should not, in itself, suggest criminalisation is inappropriate. So where does the analysis of harm that I have undertaken leave the offence?

\footnotetext{
${ }^{160}$ Human Rights Joint Committee, above n 149, para 1.178.

${ }^{161}$ Home Office, above n 4, p 1.
} 
With regards to the morality based rationale pertaining to offence to others, I have argued that the bare knowledge offence caused by the private possession of NPPIC, even if profound, can only justify criminalisation on the basis of legal moralism, since it does not constitute a wrong to the offended parties. The moral harm argument relating to depravity and corruption would have to be applied on a paternalistic basis to legitimate criminalisation, given that the offence criminalises possession rather than publication or dissemination. And in applying this rationale to an individual who has created the image he is in possession of, we would have to accept that it is possible for someone to be recorrupted by his pre-existing depraved thoughts when these thoughts are transferred into an image. Otherwise, the act of possessing such an image would not be the cause of his depravity and corruption. I would question whether even a legal moralist or fundamental moral paternalist would be won over by these rickety morality based rationales for the offence.

Returning to the matter of harm, to reiterate, harm may be caused to children by NPPIC that depict real child sexual abuse, and images that depict the fantasy sexual abuse of a real, recognisable child. Adopting a liberal humanist approach, the objectification argument supports the case for criminalising all NPPIC, although normatively, it provides a more justifiable basis for prohibiting the creation and distribution of NPPIC, given that those who possess NPPIC do not propagate harmful attitudes towards children. It is extremely difficult to find a legitimate basis for criminalising the possession of fantasy NPPIC through a reasoned application of the harm principle. If the Government had wanted to 
present the most legitimate case for criminalisation on the basis of harm to children, then the offence should have been directed to NPPIC featuring real children or real child sexual abuse by including a defence regarding fantasy, completely fabricated images. In drafting these provisions without such a defence and adopting this broad-brush approach, it seems that the legislature is either relying on harm without any proof or reasoned analysis of harm, and/or has deemed that legal moralism provides sufficient grounds to warrant criminalisation.

This poses, or should pose, real concerns in a liberal society, not least because of the human rights concerns that I have discussed and the extremely broad law-making power with which this basis for criminalisation provides legislators. And such an approach is likely to result in the creation of further offences. In the context of material which relates to child sexual abuse, it could lead to calls to criminalise written, fictitious material that is deemed to be indecent rather than obscene and thus not caught by the OPA, the offences relating to indecent photographs of children, or the new NPPIC offence. The questions that should be asked are whether criminal law's escalating intervention is likely to offer any better protection to children, and how far we are prepared to move away from the persuasive classical liberal harm-based rationale of criminalising images of real child pornography. 